\title{
The Impact of Audit Committee's Effectiveness, Gender, and Tenure on Audit Report Lag: Indonesian Evidence
}

\author{
Kayleen $^{1}$, Senny Harindahyani ${ }^{2}$ \\ \{kayleenm97@gmail.com ${ }^{1}$, senny.h@staff.ubaya.ac.id ${ }^{2}$ \}
}

University of Surabaya, Jalan Raya Kalirungkut, Surabaya, 60293, East Java, Indonesia ${ }^{1}$,
University of Surabaya, Jalan Raya Kalirungkut, Surabaya, 60293, East Java, Indonesia ${ }^{2}$

\begin{abstract}
The purpose of this research is to find the effect of audit committee's effectiveness, gender, and tenure on audit report lag for all non financial public companies listed in IDX during 2015-2017. Peraturan Otoritas Jasa Keuangan Nomor 55/POJK.04/2015 regarding Establishment and Guidelines for the Implementation of Audit Committee as the recent updated regulation is used in this research. This research employed quantitative approach using multiple linear regression with total samples of 802 companies. The result of linear regression test gives empirical evidence that audit committee's effectiveness, gender, tenure, and together with control variables contribute significant influence on audit report lag. The result of the test shows that there is a significant negative relationship between audit committee effectiveness to audit report lag. On the contrary, the relationship between audit committee's gender and tenure is insignificant towards audit report lag.
\end{abstract}

Keywords: audit committee effectiveness, audit committee gender, audit committee tenure, audit report lag, financial condition, company size, type of auditor.

\section{Introduction}

Financial statements have a purpose to provide information about the company's financial position, performance and cash flow that is useful for most users of the report in order to make economic decisions and show management's stewardship for the use of resources entrusted to them. Many parties use financial reports including investors, management, and the government. For investors, financial statements are useful to help determine whether to buy, hold or sell their investment. For the financial statement management, it is used as consideration in the preparation of the company's activity plan in the coming period. For the government, financial statements are used to regulate the activities of companies, establish tax policies and as a basis for compiling national and other income statistics.

In accordance with IFRS framework, financial statements as information will be useful if the information is provided in a timely manner for decision makers before the information loses its ability to influence in decision making. Compliance in submitting timely and accurate financial reports for public companies in Indonesia is regulated by IDX and Badan Pengawas Pasar Modal (BAPEPAM). With the enactment of Undang-Undang Nomor 21 Tahun 2011, the functions, duties and authorities of regulating and supervising the activities of financial services in the capital market sector have shifted from BAPEPAM and Lembaga Keuangan (LK) to Otoritas Jasa Keuangan (OJK) starting from December 31, 2012. Regarding the 
submission of annual reports, Peraturan Otoritas Jasa Keuangan No.29/ POJK.04/ 2016 requires companies to submit their annual reports within four months after the end of the company's financial year.

Audit committee is the representative of shareholders where audit committees have the authority and responsibility to oversee final preparation of the financial statements and the audit, including the appointment of external auditors hire by the public company. The role and responsibility of the audit committee is to monitor and supervise the audit of the financial statements and ensure that the applicable financial standards and policies are met, reexamine the financial statements whether they are in accordance with these standards and policies and whether they are consistent with other known information by members of the audit committee, as well as assessing the quality of service and the fairness of the costs proposed by external auditors [1]. Audit committee formation in Indonesia was voluntary and made mandatory after the issuance of BAPEPAM rule regarding the Establishment and Guidelines for the Implementation of Audit Committee work. Some studies tend to support the existence of audit committees because they improve the quality of financial reporting.

One of the qualitative attributes in financial statements of useful information is timeliness. The shorter the time between the end of the accounting year and publication date, the more beneficial the audited annual reports will be. The relevance of the information communicated will be lost if it is late delivered, therefore the financial statements must be presented in timely manner. If the information is not delivered on time, it causes the value of the information to be reduced in decision making for the basis of determining the future action. This increase in accurate and timely information needs has affected the demand for financial statement audits.

Timely reporting in emerging capital markets which information is relatively limited is important in order to reduce information asymmetry and affect deci-sion making. The process of achieving timeliness, especially in financial reporting, is becoming increasingly difficult, given the increasing development of public companies in Indonesia. This obstacle in timeliness is also evident from the audit standards of public accountants in the third standard which states that audits must be carried out with due diligence and thoroughness and collection of sufficient evidence tools. With these obstacles, it is possible for public accountants to postpone the publication of audit reports and audited financial statements if it is deemed necessary to extend the audit period [2].

This study examines the factors that influence the behavior of financial reporting in a timely manner. The factors that will be tested in this research are audit committee effectiveness (independence, expertise, audit committee charter, audit committee size, audit commit-tee oversight responsibilities, meeting by audit committee and voluntary disclosure), gender, and tenure of the audit committee's members. The sample of all public companies listed in ww.idx.co.id for the year 2015-2017 [3]. This study uses recent regulation namely Peraturan Otoritas Jasa Keuangan Nomor 55/POJK.04/2015 while prior study examines using Keputusan BAPEPAM dan LK Nomor Kep-643/BL/2012 with additional attachment Peraturan Nomor IX.I.5 re-garding Establishment and Guidelines for the Implementation of Audit Committee work. The requirement of having audit committee charter on a company's website was voluntary but made mandatory after the issuance of Peraturan Otoritas Jasa Keuangan Nomor 55/POJK.04/2015. This study also adds another independent variables that may affect the financial reporting timeliness namely gender and tenure of audit committee. Previous studies have examined the impact of the number of female members in an audit committee that links with gender role theory towards its implication on audit report lag. There are several studies regarding audit committee tenure namely, audit committee tenure to restatement of financial statements [4], audit committee tenure to earning management [5], 
audit committee tenure to voluntary ethics disclosure [6], and audit committee tenure to investment in in-ternal auditing [7].

\section{Theoretical Framework and Hypotheses}

\subsection{Agency Theory}

This research is based on the agency theory which is used by a company to understand corporate governance. This theory discuss the relationship between principal (shareholder) and agent (management). Agency relationship is a contract between one or more people who hire another person to provide a service and then delegate decision-making authority to the agent .

Agency theory is based on several assumptions that are divided into three types; human nature assumption, organizational assumption and information assumption [8]. Based on the assumption of human nature, it is explained that individual problems are solely motivated by their own interests so that they cause a conflict of interests between principals and agents. Principals are motivated to enter into a contract for the sake to prosper himself with always increasing profitability. On the other hand, managers are motivated to maximize economic fulfillment and psychology, among others, in obtaining investments, loans, and compensation contracts. Therefore, there are two interests within the company where each party strives to achieve or maintain the desired level of prosperity.

Problems that arise as a result of different interest between principal and agent is called agency problems. This problem persisted since the evolution of the joint stock companies and has taken different shapes in various forms and various costs involved in order to minimize the problem [9]. One of the causes is because of information asymmetry upon which principals do not have enough information about the agent's performance whereas the agent has more information regarding self-capacity, the workforce and the company as a whole [10]. Agency theory is used by the audit committee to understand the arising conflict of interest between shareholders and management. Principal as an investor cooperates and signs a work contract with the management of the company to invest their funds. With the existence of an independent audit committee, it is expected that there will be no fraud in the financial statements prepared by management which can result in audit report lag and at the same time can be used to evaluate the performance of the management that is useful for investors in process of decision making.

\subsection{Audit Report Lag}

Timely information is information available to decision makers before the information loses its capability to influence decisions [11]. The lag in financial statements publication can lead to uncertainty about investment decisions. Timely reporting will trigger the level of decision making and reduce information asymmetry in the market [12]. This study uses Audit Report Lag (ARL) as a proxy of financial reporting timeliness. In Indonesia, public companies are obliged to submit their annual report periodically. Otoritas Jasa Keuangan (OJK) announced that annual report should be submitted at least at the end of fourth month after the statement date (120 days). Financial reporting time decision is an important element in making investment decisions. One of the obligations of companies that have gone public is to publish financial statements so that interested parties can find out the position of the company's profitability. However, not all companies can publish it on time. Delay in financial reporting indicates a problem in the issuer's financial reporting, which requires a longer settlement time. Delay in financial reporting can be caused by companies trying to gather a lot of information to guarantee the reliability of financial statements. 


\subsection{Audit Committee}

Previous study investigated the effect between audit committee and reporting of timeliness and use audit committee as one of the proxies in determining audit report lag [13]. In the case of financial reporting, the role and responsibility of the audit committee is to monitor and supervise the audit of the financial statements and ensure that the prevailing financial standards and policies have been met, reexamine the financial statements whether they are in accordance with the standards and policies and are consistent with other information known to members of the audit committee, as well as assessing the quality of service and the fairness of the costs proposed by external auditors. Thus audit committee has an important role in the preparing process of a timely annual reports. Asian financial crisis in 1997 has initiated the regulation of audit committee in Indonesia. Initially, audit committee formation was voluntary and made mandatory after the issuance of BAPEPAM rule (2003 amended in 2004).

Several provisions and regulations in Indonesia regarding the audit committee have been announced in Keputusan BAPEPAM dan LK Nomor Kep-643/BL/2012 with additional attachment Peraturan Nomor IX.I.5 that has been shifted to recent regulation of Peraturan Otoritas Jasa Keuangan Nomor 55/POJK.04/2015 regarding the Establishment and Guidelines for the Implementation of Audit Committee work.

\subsection{Audit Committee Effectiveness}

Audit committee is said to be effective if it has qualified members with the authority and resources to protect stakeholder interests by ensuring reliable financial reporting, internal controls, and risk management through diligent oversight efforts [14]. Audit committee effectiveness is measured by using DeZoort audit committee effectiveness Framework (2002). In this study, all requirements are extracted from Peraturan Otoritas Jasa Keuangan (POJK) Nomor 55/POJK.04/2015 regarding Establishment and Guidelines for the Implementation of Audit Committee work in Indonesia. Therefore, there are 7 components used in this study namely independence, expertise, oversight responsibilities (review financial statement, review external auditor, review internal control, review compliance with regulation), charter, meetings held during financial year, and voluntary disclosure. The scoring process for each requirement will be as follows: a company will be given score 1 if a company complies with a particular requirement and 0 otherwise. However, the scoring process for responsibility in authority element is assessed based on certain criteria, namely if a company provides a brief statement regarding responsibility then it will be given score 1 , if a company provides detail explanation (i.e. not only describes but also explains the actions on how to perform a particular responsibility by stating the scope and the result of the review) then it will be given score 2 , and 0 if there is no disclosure at all. Companies with audit committee that fulfills all assessment will get total highest score of 14 . Higher score indicates more effective audit committee.

\subsection{Audit Committee Gender}

Gender refers to a set of characteristics that are considered to distinguish between men and women. Gender reflects a person's biological sex or reflects a person's gender identity [15]. A study by Meyers and Levy (1986) defines gender as one of the individual factors that influence work attitudes. Females are more financially conservative, ethically bound, and riskaverse than males [16]. This study examines gender of audit committee which is the percentage of female members in an audit committee. In gender role theory, it is found that men are tend to produce risky choices and dominate managerial structure in a company [17]. 
The distinguishment between characteristics of man and woman in audit committee will cause the differentiation between the time of completing a task and submission of audited financial statements.

\subsection{Audit Committee Tenure}

Audit committee with long tenure may compromises in independence and significantly affect financial reporting quality [18]. The audit committee tenure has become the focus of several debates. Many results lead to dilemma that the firm is faced with the decision of whether to replace its audit committee members after a short period of time or to build and maintain a long-term tenure. Empirically, prior research [19] documents that outside director of audit committee member's tenure reflects higher monitoring effectiveness since they possess greater experience and expertise in monitoring financial reporting process. However, long board tenure outside directors may have a friendly relationship with the management, which could be developed over time [5] since the management may be involved in the nomination process of outside directors, outside directors who have strong personal ties with the management are more likely to be reappointed and survive long term. Those directors' independence could be impaired by their amiable relationship with managers. Moreover, long board tenure directors are less mobile and less employable, and lack new insights and solutions to the company's issues [20]. Thus, it is possible that thenegative effects offset its positive effect of long board tenure on monitoring effectiveness.

\subsection{Hypothesis Development}

The effect between audit commitee effectiveness and reporting lead time and found that audit commitee effectiveness is a significant variable influencing timeliness of reporting [3]. More effective audit committee will result in shorter audit delay thus comply with applicable regulations. Another study also examined 5 proxies of audit committee effectiveness (expertise, charter, meetings, independence, size) and the result also shows that more effective audit committee will reduce the financial reporting lead time of a company to publicly released audited financial statements [21]. Thus, it can be hypothesized that:

\section{H1 : Audit commitee effectiveness has negative effect to ARL.}

Gender role theory in the research of Amanatullah et al. (2010) stated that in decision making, men tend to produce risky choices, whereas women tend to show safer choices in decision making. Gender differences in audit committees are expected to provide a more effective role in the oversight function of the financial reporting process which can encourage management to publish financial statements in a timely manner.

Meyers and Levy (1986) states that when compared to men, women generally have a tendency to work more thoroughly and neatly in completing their tasks and tend to carry out tasks better. This will greatly help public accountants in verifying financial reports so that they can speed up the audit process. Therefore, it can be hypothesized :

\section{H2 : Audit committe gender has negative effect to ARL.}

There are still few studies examine the effect between audit committee tenure and ARL. Previous studies about audit committee tenure try to find the effect between audit committee tenure and restatement of financial statements [3][4], audit committee tenure and earning 
management [5], audit committee tenure and voluntary ethics disclosure [6], audit committee tenure and investment in internal auditing [7].

Independent directors with long board tenure will have greater experience and expertise in monitoring financial reporting process since work experience can improve job performance as experience is the job-relevant knowledge gained over time [22]. Since long board tenure outside directors possess greater knowledge and experience, they may have higher monitoring effectiveness than other outside directors. Long board tenure of audit committee members may have greater experience, expertise, reputation, commitment, and willingness to performance better. Thus, an independent audit committee with longer tenure may have higher monitoring effectiveness thus shorter ARL. Longer audit tenure means the auditor's understanding of operations, business risks, and accounting systems of the company also increase, resulting in more efficient audit processes.

However, long board tenure may affect relationship with the management, which could be developed over time. Long board tenure directors are less mobile and less employable, and lack new insights and solutions to the company's issues [20]. Since the management may be involved in the nomination process of audit committee member, audit committee who has personal ties with the management are more likely to be reappointed and survive long term. Those members' independence could be compromised by their close relationship with managers. Thus, it is possible that the positive effect of long board tenure on monitoring effectiveness is offset by its negative effect. Therefore, it can be hypothesized :

\section{H3 : There is significant effect from audit committe tenure to ARL.}

\section{Research Method}

This study is explanatory research which is to identify and explain about the impact of audit committee effectiveness, gender, and tenure to audit report lag in indonesian listed companies during 2015-2017 from Indonesia Stock Exchange (IDX) website. This study also explain cause and effect relationship between independent variables to dependent variables.

Table 1. Sample Selection

\begin{tabular}{l|llll}
\hline Description & $\mathbf{2 0 1 5}$ & $\mathbf{2 0 1 6}$ & $\mathbf{2 0 1 7}$ & Total \\
\hline Data of all companies listedin IDX for the period 2015-2017 & 517 & 534 & 606 & 1.657 \\
Financial sector companies & -87 & -89 & -88 & -264 \\
Using foreign currency & -54 & -58 & -56 & -168 \\
Incomplete data & -114 & -107 & -185 & -406 \\
Outliers data & -7 & -5 & -5 & -17 \\
Total samples & 255 & 275 & 272 & 802 \\
\hline
\end{tabular}

\subsection{Population and Sampling Techniques}

Target population used is all non financial public companies listed in www.idx.co.id for the period 2015-2017. This study uses non-probability sampling where element in the population do not have any probabilities of being chosen as sample. Next, purposive judgmental sampling will be used with the aim to find specific sample that fulfills relevant sample to this study.

The followings criteria for the sample in this study are:

1. The company is listed on the IDX. 
2. The company is engaged in sectors other than finance.

3. The company does not use any currency others than rupiah.

4. The company fully discloses the data needed in this study.

The analytical method used in this study is a simple regression analysis. This regression analysis aims to obtain a comprehensive picture of the relationship between the independent variable and the dependent variable both partially. Before carrying out a comprehensive regression test, it is necessary to test the classical assumptions first in order to get the best results [3]. In using simple regression, avoid the possibility of deviations from classical assumptions. The purpose of fulfilling classic assumptions is to mean that the independent variable as an estimator of the related variable is not biased.

\section{Data Analysis and Discussion}

This study uses multiple linear regression in conducting hypothesis testing. The results of the partial test ( $t$ test) shows that ACEF is significantly negative to ARL, GENDER is insignificantly negative towards ARL, and TENURE is insignificantly positive towards ARL.

Table 2. Partial Test (t-Test)

\begin{tabular}{c|ccc}
\hline Model & t & Sig. & Sig/2 \\
\hline (Constant) & 14,723 & 0,000 & 0,000 \\
ACEF & $-3,582$ & 0,000 & 0,000 \\
GENDER & $-0,420$ & 0,675 & 0,3375 \\
TENURE & 0,005 & 0,996 & 0,498 \\
ZFC & 2,003 & 0,046 & 0,023 \\
SIZE & $-5,871$ & 0,000 & 0,000 \\
BIG 4 & 0,111 & 0,912 & 0,456 \\
\hline
\end{tabular}

In table 2, the result of the $t$ test shows audit committee effectiveness with significance value of 0,000 with value of $t$ count of $-3,582$ and coefficient value of -1.113 . The result shows that ACEF has a statistically significant negative effect on ARL. Negative sign is interpreted that the more effective an audit committee is, the company can reduce the ARL or deliver timely financial reporting. This result is consistent with previous research which shows that there is a negative effect between ACEF and ARL [3]. This study also supports another study which examined 5 proxies of audit committee effectiveness and shows that more effective audit committee will reduce the financial reporting lead time of a company to publicly released audited financial statements [21]. The result of this study indicates that audit committee in Indonesia is effective in improving one of the quality of financial reporting which is timeliness. Having an effective audit committee is expected to solve the agency theory problem that arises as a result of different interest between management and shareholders thus reduce information asymmetry.

This study finds that there is no significant effect from GENDER to ARL. It is statistically proven with significance value that is greater than 0.05 . This result is contrary with previous research that finds GENDER has negative and significant effect on ARL [15]. 
The result of $t$ test shows that GENDER insignificantly affect ARL which depicted by significance value of 0.3375 with $t$ value of -0.420 . Negative sign is interpreted that more females in a audit committee will result in shorter ARL. Previous study by Sari and Supadmi (2014) found that GENDER has significantly negative effect on ARL. However, this study finds that GENDER has negative effect on ARL but not significantly. This happened because of a regulation that requires go public companies to submit their financial reports within four months after the financial statement date thus the audit committee members both man and woman will try to deliver the financial statements in a timely manner. Binding regulation regarding the submission of audited annual reports made audit committee tend to produce more timely financial reporting and avoids administrative sanctions. Moreover, this study finds that there is still few existence of female members in an audit committee as indicated by the small percentage of audit committees that have female members. This study finds that audit committee with no female members at all consists of 495 sample data which is $61.72 \%$ of population. Therefore it less reflecting differences between male and female members of an audit committee thus ARL is not significantly affected by GENDER. Test result shows that there is no significant effectfrom TENURE to ARL. TENURE has significance value of 0.996 with $\mathrm{t}$ value of 0.005 . Values of $\mathrm{t}$ indicates positive sign, however the significance value is greater than 0.05 which means audit committee tenure has insignificant effect on ARL. Positive sign is interpreted that longer tenure will cause longer submission of company's annual reports (longer ARL). However, the result of this study is contrary with previous research that shows longer tenure will cause higher monitoring [23] which then assumes reducing the company's submission of annual reports (shorter ARL).

Previous studies have shown that audit committee tenure has significant effect on restatement of financial statements [4], earning management [5], voluntary ethics disclosure[6], and investment in internal auditing [7] but none has shown that audit committee tenure has significant effect on ARL. One possible reason that there is no correlation between audit committee tenure and ARL is this study is that audit committee tenure is not the main variable that directly affect ARL. Another possible reason is that the number of tenure in this study varies for each members of the audit committees. There is possibility that gap may varies in each audit committee members (one may have longer tenure while another may just served as an audit committee). Thus, these gaps cause insignificant effect of TENURE to ARL.

Table 3. Multiple Linier Regression Result Table

\begin{tabular}{lcc}
\hline Model & \multicolumn{2}{c}{ Unstandardized Coefficients } \\
& B & Std. Error \\
(Constant) & 145,213 & 9,863 \\
ACEF & $-1,113$ & 0,311 \\
GENDER & $-0,853$ & 2,031 \\
TENURE & 0,001 & 0,251 \\
ZFC & 0,342 & 0,171 \\
SIZE & $-2,032$ & 0,346 \\
BIG 4 & 0,129 & 1,171 \\
\hline
\end{tabular}


Table 3 shows the result for multiple regression for hypothesis testing. A constant of 145.213 means that if ACEF, GENDER, TENURE, ZFC, SIZE, and BIG4 do not exist or the value is 0 , then ARL is 145,123 .

ACEF regression coefficient is -1.113 means that if ACEF is increased by 1 unit, then ARL will decrease by 1,113 . A negative sign indicates that there is a reverse relationship between ACEF and ARL. So that if the ACEF is increased, it will shorten ARL and companies can submit financial reports on time or before the deadline that has been set.

GENDER regression coefficient is -0.853 which means that if GENDER is increased by 1 unit, then ARL will decrease by 0.853. A negative sign indicates that there is a reverse relationship between GENDER and ARL. So that if an audit committee consist of more female members then it will increase the percentage of the GENDER variable and shorten the ARL.

TENURE regression coefficient is 0.001 meaning that if TENURE is increased by 1 unit, then ARL will experience a relatively small increase of 0.001 . A positive sign indicates that there is a parallel relationship between TENURE and ARL. So that if the audit committee tenure is longer, it can lead to longer ARL.

$\mathrm{ZFC}$ regression coefficient of 0.342 means that if $\mathrm{ZFC}$ is increased by 1 unit, then ARL will increase by 0.342 . A positive sign indicates that there is a parallel relationship between ZFC and ARL. So, if a company is experiencing a bad financial condition that is marked by increasing ZFC index, it can cause longer ARL.

SIZE regression coefficient is $-2,032$ which means that if SIZE is increased by 1 unit, then ARL will decrease by 2,032. A negative sign indicates that there is a reverse relationship between SIZE and ARL. So, the bigger and more complex a company will cause shorter ARL. BIG4 regression coefficient of 0.129 means that if BIG4 is increased by 1 unit, then ARL will increase by 0.129 . A positive sign indicates that there is a parallel relationship between BIG4 and ARL. So, if a company uses auditors from BIG 4, then the possibility of ARL will be longer.

\section{Conclusion, Implication, Suggestion, and Limitations}

This study aims to determine the effect of audit committee effectiveness, gender, and tenure on ARL. Based on the analysis of the results of testing the data and the discussions that have been conducted, a conclusion can be taken :

1. The effectiveness of the audit committee significantly affects ARL. This means that an increasingly effective audit committee can influence the delivery of more timely financial reports and shorten ARL.

2. The number of female members in an audit committee has no significant effect on ARL.

3. The tenure of the audit committee has no significant effect on ARL.

4. The company's financial condition and company size have a significant influence on ARL.

5. The type of auditor (BIG 4 or non BIG4) does not have a significant effect on ARL.

The hypothesis testing result in this research shows that audit committee effectiveness and company's size have significant negative effect on audit report lag whereas company's financial condition has significant positive effect on audit report lag. Moreover, the rest variables in this research namely audit committee gender, audit committee tenure, and type of auditor do not have significant effect towards audit report lag. The result of this research shows 
that there is information assymetry indicated by late submission of company's annual report upon which the information is late delivered to the information's users thus lead to agency problem. With the existence of an independent audit committee, it is expected that the more effective audit committee will result in company to submit annual report in timely manner thus information will not be late delivered.

For companies, this research can be used as a consideration in the forming of the audit committee. Companies should consider regarding the effectiveness of audit committee since audit committee holds an important role in the process of preparing financial statement until it is going to be published.

For standard and regulations setters, this study gives information that there are several companies in Indonesia that still late in submitting their annual reports (more than 120 days). Moreover, audit committee in several companies in Indonesia also do not comply with the applicable regulation namely, Peraturan Otoritas Jasa Keuangan Nomor 55/POJK.04/2015.

For academicians and researchers, this research contributes in the development of knowledge regarding the effect of audit committee effectiveness, gender, and tenure on audit report lag. Moreover, this research is expected to be useful as a basis in future research.

In this study, researchers are faced with several limitations and constraints, namely:

1. Initially, this study consists of samples that have many outliers so researcher has to throw out several extreme outliers.

2. To find the tenure variable, the researcher must trace the tenure of each member of the audit committee back through the information in the annual report and on the notes to the financial statements. However, in some samples there are limitations due to the absence of financial reports available for the previous years so the researcher must eliminate the sample.

3. Regarding the measurement of audit committee effectiveness, this study only uses external available information (audited annual reports) without having direct interaction in order to gather data.

This study suggest future research to not only rely on external available information but also conduct interaction with audit committee members such as survey and interview, classify the tenure of audit committee to avoid huge gap in the audit committee tenure variable, and adding more relevant components regarding the assessment of audit committee effectiveness.

\section{References}

[1] S. Karo-karo and J. Perlantino, "PENGARUH CORPORATE GOVERNANCE, KUALITAS KAP, FIRM SIZE, DAN LEVERAGE TERHADAP INTEGRITAS LAPORAN KEUANGAN PADA PERUSAHAAN PROPERTY DAN REAL ESTATE YANG TERDAFTAR DI BURSA EFEK INDONESIA PERIODE 2013 2015," Jakpi, vol. 05, no. 01, pp. 102-122, 2017.

[2] W. Utami, "ANALISIS DETERMINAN AUDIT DELAY KAJIAN EMPIRIS DI BURSA EFEK JAKARTA,” Bull. Penelit., no. 9, pp. 19-32, 2006.

[3] S. R. Ika, "Audit committee effectiveness and timeliness of reporting : Indonesian evidence," vol. 27, no. 4, pp. 403-424, 2012.

[4] J. S. Yang and J. Krishnan, “Audit Committees and Quarterly,” vol. 219, pp. 201-219, 
2005.

[5] G. Liu, J. Sun, and J. Sun, "Director tenure and independent audit committee effectiveness Director Tenure and Independent Audit Committee," 2010.

[6] R. Othman, I. Farhana, S. Maznah, M. Arif, and N. Abdul, "Influence of audit committee characteristics on voluntary ethics disclosure," Procedia - Soc. Behav. Sci., vol. 145, pp. 330-342, 2014.

[7] A. Barua, D. V Rama, and V. Sharma, "J . Account . Public Policy Audit committee characteristics and investment in internal auditing," J. Account. Public Policy, vol. 29, no. 5, pp. 503-513, 2010.

[8] L. M. Ifada and G. Kurniawan, "MEKANISME CORPORATE GOVERNANCE, MANAJEMEN LABA DAN KINERJA KEUANGAN," EKOBIS, vol. 12, no. 1, pp. 27-39, 2011.

[9] B. Panda and N. M. Leepsa, "Agency theory : Review of Theory and Evidence on Problems and Perspectives," 2017.

[10] A. U. Widyaningdyah, "TERHADAP EARNINGS MANAGEMENT PADA PERUSAHAAN GO PUBLIC DI INDONESIA," 1997.

[11] Financial Accounting Standards Board, "Conceptual Framework for Financial Reporting," no. 8, 2018.

[12] S. Owusu-ansah and S. Leventis, "Timeliness of corporate annual financial reporting in Greece," no. October 2013, pp. 37-41.

[13] H. A. E. Afify, "Determinants of audit report lag Does implementing corporate governance have any impact? Empirical evidence from Egypt," J. Appl. Account. Res., vol. 10, no. 1, pp. 56-86, 2009.

[14] F. T. Dezoort, D. R. Hermanson, and S. A. Reed, "Audit Committee Effectiveness : A Synthesis of the Empirical Audit Committee Literature," 2002.

[15] M. M. R. Sari and N. L. Supadmi, "GENDER KOMITE AUDIT DAN AUDIT DELAY," J. Ilm. Akunt. dan Bisnis, vol. 9, no. 2, pp. 65-72, 2014.

[16] J. P. Byrnes, The Nature and Development of Decision Making: A Self-Regulation Model. New York: Lawrence Erlbaum Associates, Inc, 2011.

[17] H. Kang, M. Cheng, and S. J. Gray, "Corporate Governance and Board Composition : diversity and independence of Australian boards," vol. 15, no. 2, pp. 194-207, 2007.

[18] N. DOPUCH, R. R. KING, and R. SCHWARTZ, "An Experimental Investigation of Retention and Rotation Requirements," J. Account. Res., vol. 39, no. 1, pp. 93-117, 2001.

[19] D. A. N. Dhaliwal, V. I. C. Naiker, and F. Navissi, "The Association Between Accruals Quality and the Characteristics of Accounting Experts and Mix of Expertise on Audit Committees *," Contemp. Account. Res., vol. 27, no. 3, pp. 787-827, 2010.

[20] N. VAFEAS, "Length of Board Tenure and Outside Director Independence," J. Bus. Financ. Account., vol. 30, no. October, pp. 1043-1064, 2003. 
[21] A. A. Oussii and N. B. Taktak, "Audit committee effectiveness and financial reporting timeliness : The case of Tunisian listed companies," African J. Econ. Manag. Stud., 2016.

[22] F. Fiedler, "Leadership Experience and Leader Performance-- Another Hypothesis Shot To Hell 1," Organ. Behav. Hum. Perform., vol. 4, no. 454, pp. 1-14, 1970.

[23] A. Moung, Y. Chan, G. Liu, and J. Sun, "Independent audit committee members ' board tenure and audit fees," no. April 2012. 